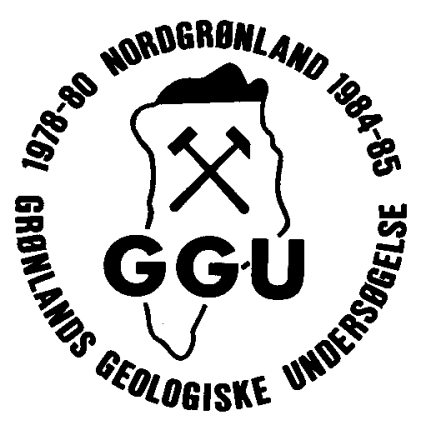

\title{
The Silurian turbidite sequence of the Peary Land Group between Newman Bugt and Victoria Fjord, western North Greenland
}

\author{
Poul-Henrik Larsen and Jan C. Escher
}

\begin{abstract}
Several lithological units of the Silurian Peary Land Group show a remarkable continuity along the $\mathrm{E}-\mathrm{W}$ trending basin axis, but pronounced lateral facies changes occur $\mathrm{N}-\mathrm{S}$ across the basin. An approximately $4000 \mathrm{~m}$ thick sequence of turbidites to the north in the deep-water basin represents the time equivalent of about $1065 \mathrm{~m}$ of turbidites, slope sediments and platform carbonates at the basin margin to the south.

Ellesmerian regional deformation affected the northern part of the area showing a progressive increase of deformation of the deep-water sequence from south to north. The general structural pattern suggests a lithological anisotrophy within the upper part of the crust with a buried carbonate shelf to the south bounded by an escarpment towards a deep siliciclastic basin to the north. The difference in total thickness of the Llandovery to Lower Ludlow sedimentary sequence between the south and north supports this hypothesis.
\end{abstract}

P.-H. L. \& J. C. E., Grønlands Geologiske Undersøgelse, Øster Voldgade 10, DK-1350 Copenhagen K, Denmark.

An area of about $11000 \mathrm{~km}^{2}$ of the Peary Land Group was mapped in Nyeboe Land, Hendrik $\varnothing$, Castle $\varnothing$, Warming Land, Permin Land, Wulff Land and Stephenson $\emptyset$ during the summer of 1984 as part of the 1984-1985 regional mapping program. The main stratigraphical and structural data collected are briefly described in this paper.

Prior to the fieldwork we were generously assisted by P. R. Dawes, J. M. Hurst and F. Surlyk who provided us with many unpublished observations. In the field we greatly benefitted from a 1:100 000 preliminary photogeological map based partly on reconnaissance and photogeological work undertaken by P. R. Dawes during previous years, and partly on new stereoscopic studies of aerial photographs by A. K. Higgins, H. F. Jepsen and J. C. Escher.

The mapping units erected here follow the lithostratigraphic formations and members defined for the Peary Land Group by Hurst (1980) and Hurst \& Surlyk (1982), and five new mapping units are recognised in this paper. A more detailed sedimentological study of part of the sequence is presented elsewhere (Larsen \& Escher, unpublished manuscript). Our preliminary and simplified geological map (fig. 1) has been produced as a result of extensive 


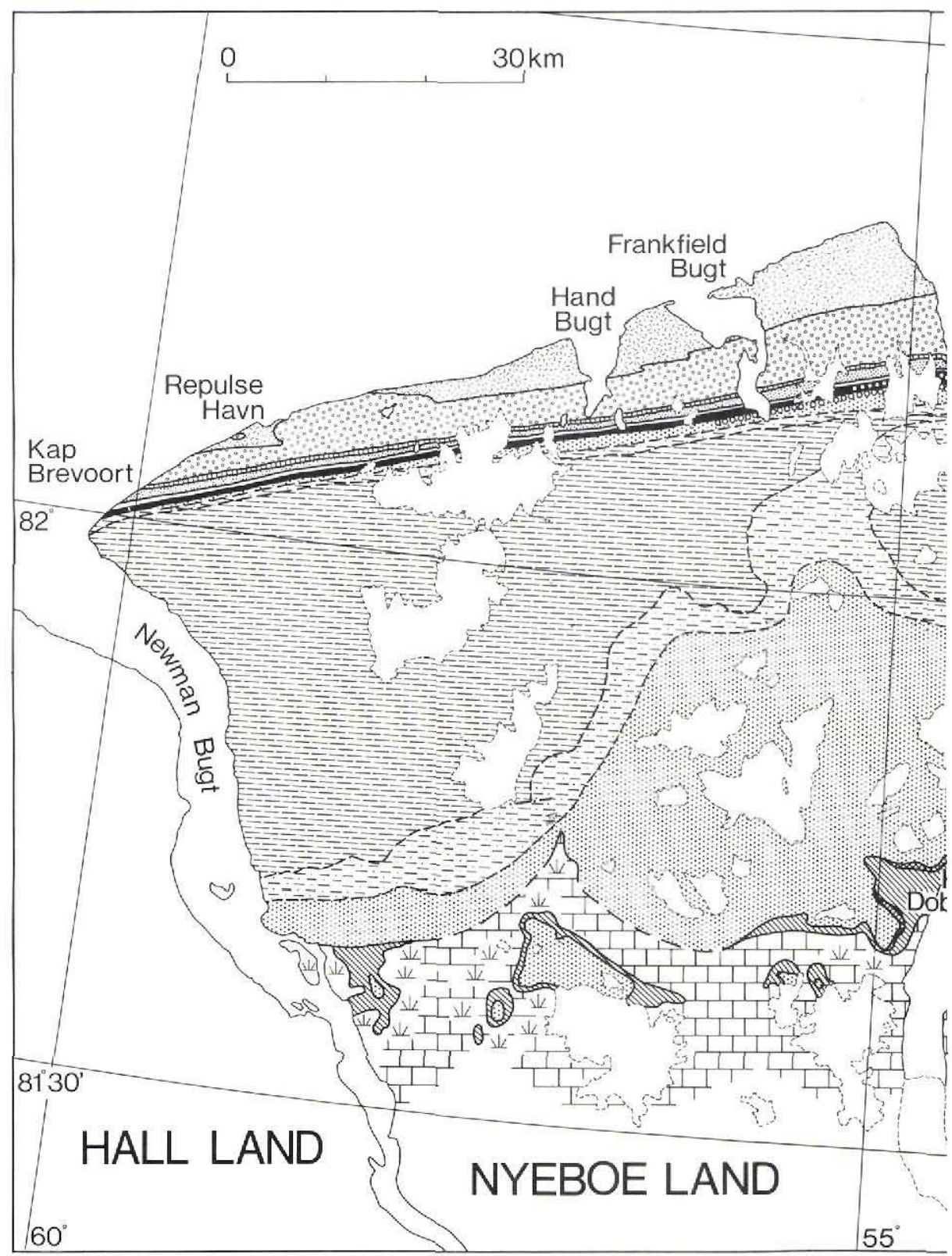

Fig. 1. Preliminary geological map of the Peary Land Group in western North Greenland (Nyeboe Land - Stephenson Ø). The map is based on field work carried out during the summer of 1984. 


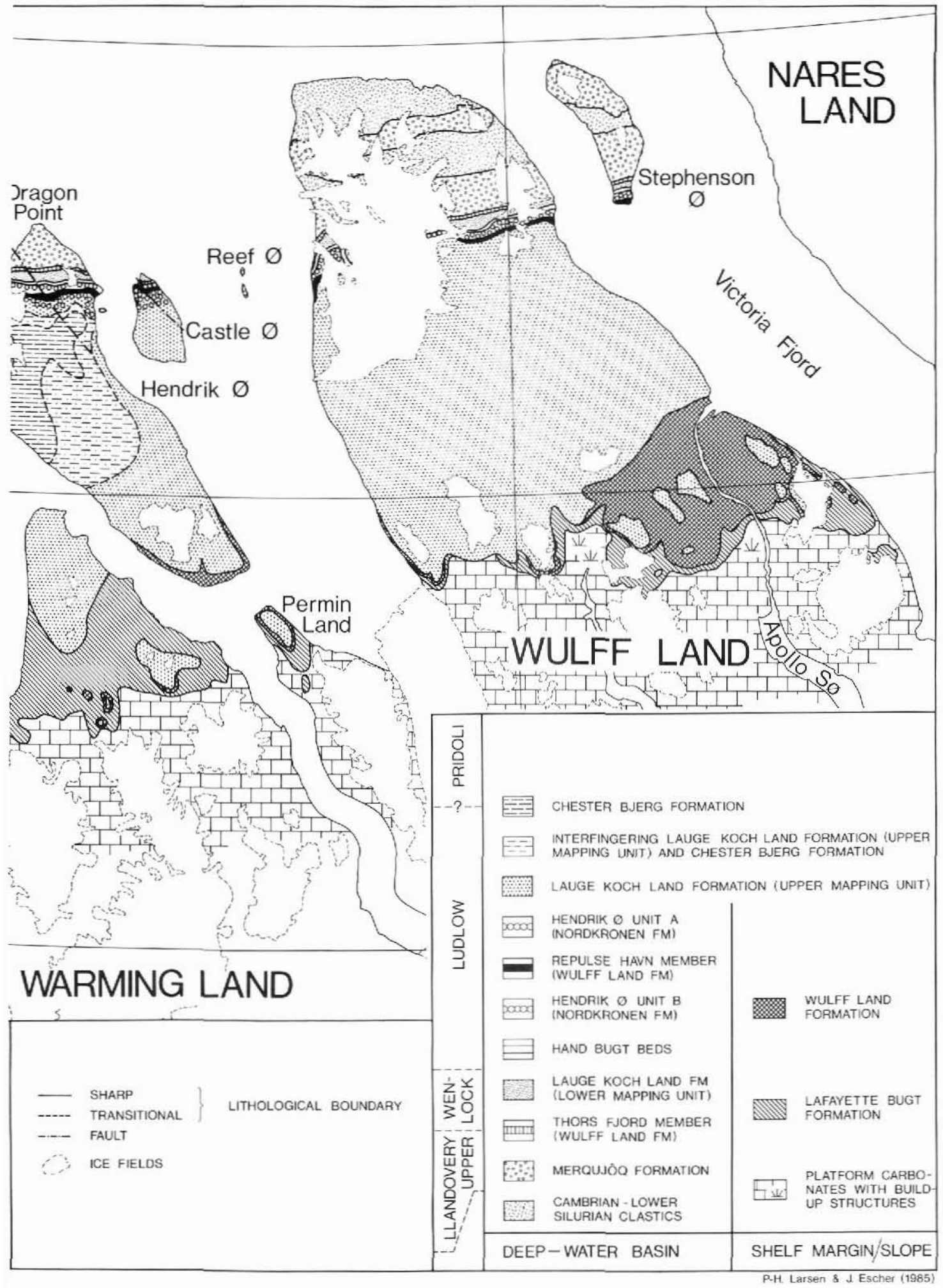




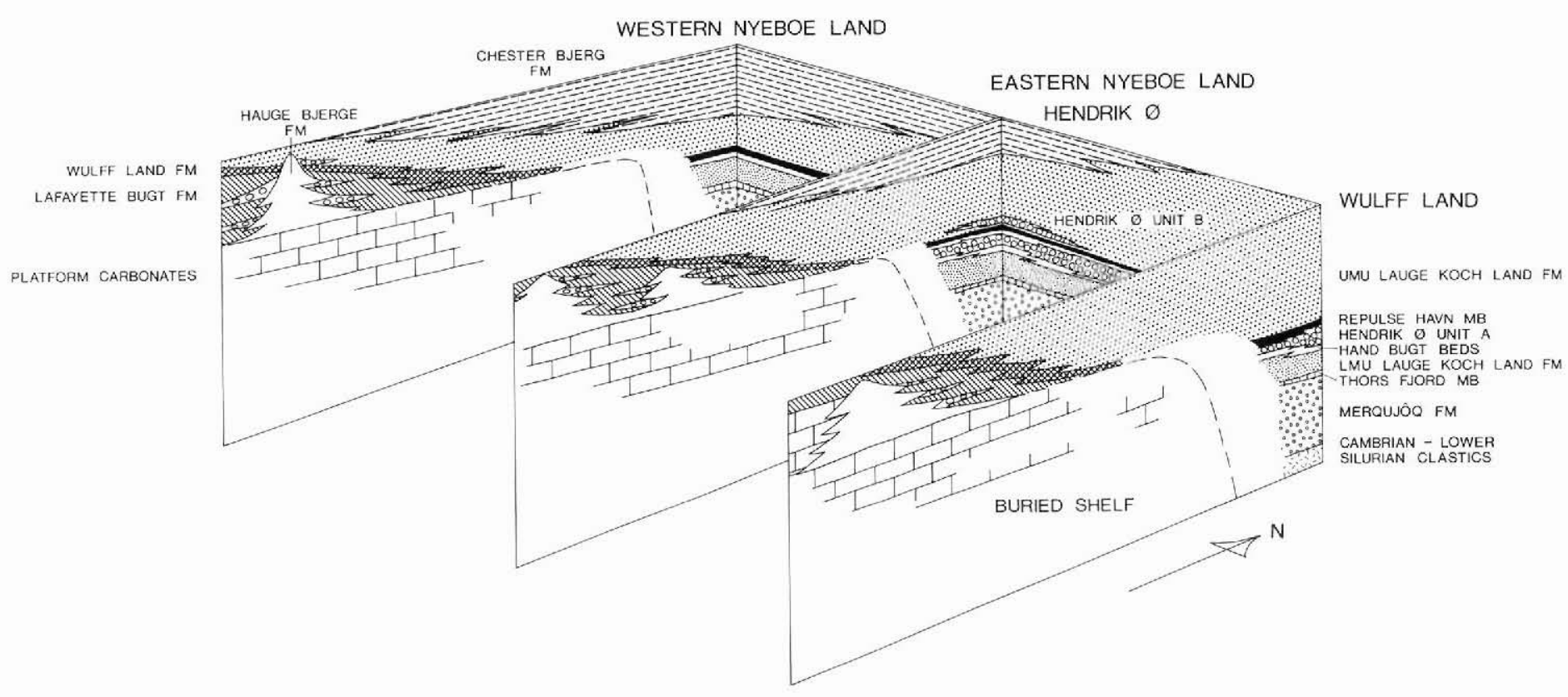

Fig. 2. Schematic conceptual diagram showing the spatial distributional patterns of the mapped lithological units and their mutual relationships. The ornamentation corresponds to fig. 1. The diagram is based on fig. 2 in Hurst \& Surlyk (1982) with new information added. 
helicopter support. It is therefore considerably more accurate and detailed than published maps based on reconnaissance (e.g. Dawes, 1976, fig. 267, 1982, fig. 4; Hurst \& Surlyk, 1982, plate 4). However, differences of mapping and interpretation will not be discussed here.

The Peary Land Group is the upper part of the Lower Palaeozoic deep-water sequence of the Franklinian Basin which extends across North Greenland and northern Ellesmere Island (Trettin \& Balkwill, 1979; Hurst, 1980; Friderichsen et al., 1982; Hurst \& Surlyk, 1982). Sediments younger than Silurian have not been recognised within the area studied, except for the Quaternary cover (fig. 1).

Earlier work on the deep-water basin of North Greenland includes Dawes (1966, 1971, 1976, 1982), Dawes \& Peel (1984), Dawes \& Soper (1973, 1979), Friderichsen et al. (1982), Higgins et al. (1982), Hurst (1980), Hurst \& Surlyk (1982, 1984), Surlyk (1982), Surlyk \& Hurst (1983, 1984), Surlyk et al. (1980).

\section{Stratigraphy}

A schematic conceptual diagram showing the spatial distributional patterns of the mapped lithological units and their mutual relationships is given in fig. 2 .

The extent of the units is shown on the geological map (fig. 1). In the north, within the east-west orientated Nyeboe Land linear belt of Dawes (1982), several units can be traced for more than $180 \mathrm{~km}$ along strike within the almost vertically orientated Silurian turbidites. This shows the remarkable persistence in continuity and thickness of these units along the east-west axis of the deep-water basin.

The areal extent, lithology, thickness and geological age of each mapping unit are briefly described below.

Sedimentological logs are standardised according to the facies scheme of Hurst \& Surlyk (1982, fig. 6) reproduced here in fig. 4 . Graptolite identifications have kindly been made by Merete Bjerreskov, University of Copenhagen.

\section{Merqujôq Formation}

The Merqujôq Formation defined by Hurst \& Surlyk (1982) is the lowermost lithostratigraphic unit of the Peary Land Group appearing only in the northern part of the deep-water basin (figs 1 \& 2). The formation is characterised by medium to thick-bedded fine sandstone turbidites of 'classical flysch' appearance. The formation overlies Cambrian - Lower Silurian starved-basin clastic sediments (Friderichsen et al., 1982; Surlyk \& Hurst, 1984; Higgins \& Soper, 1985). The Merqujôq Formation was not previously known to occur west of Wulff Land. Detailed mapping has shown that the formation makes up the main part of the steeply dipping Nyeboe Land linear belt and is traceable across Nyeboe Land, Hendrik $\emptyset$, Wulff Land and Stephenson $\varnothing$ (fig. 1); it also crops out in the core of a major syncline north of the linear belt in northern Wulff Land and Stephenson $\varnothing$ (fig. 1).

In the Wulff Land - Nyeboe Land region the Merqujôq Formation is overlain by black shales of the Thors Fjord Member of the Wulff Land Formation. At Hand Bugt in Nyeboe Land the formation is $2.8 \mathrm{~km}$ thick; this is several times larger than thickness estimates of the Merqujôq Formation in Peary Land (Hurst \& Surlyk, 1982).

Graptolite assemblages have been collected at the base of the Merqujôq Formation at six 
locations between Nyeboe Land and eastern Nansen Land (Higgins \& Soper, 1985, personal communication); these indicate a Late Llandovery age (the turriculatus Zone or the spiralis Zone) for the lowest part of the formation.

Further to the east the age of the base of the Merqujôq Formation is not well defined; at one locality in Amundsen Land, Upper Ordovician (Cincinnatian) graptolites are recorded $20 \mathrm{~m}$ below the base of the formation (Surlyk et al., 1980; Hurst \& Surlyk, 1982).

Within the uppermost $600 \mathrm{~m}$ of the Merqujôq Formation at Hand Bugt, the graptolite assemblages, including Cyrtograptus (?)sakmaricus, Monoclimacis vomerina and $M$. aff. $M$. crenulata, indicate a Late Llandovery or perhaps an Early Wenlock age. In Peary Land, the top of the formation is apparently not diachronous, at least within the resolution of the spiralis Zone of the Late Llandovery (Hurst \& Surlyk, 1982).

The above graptolite evidence indicates that the bulk of the Merqujôq Formation ( $2.8 \mathrm{~km}$ thick as measured at Hand Bugt), was probably deposited entirely within the Fronian $\left(\mathrm{C}_{2-3}\right)$ - Telychian of the Late Llandovery.

\section{Lafayette Bugt Formation}

The Lafayette Bugt Formation defined by Hurst (1980) forms a more or less continuous E-W striking narrow belt along the southern margin of the turbidite basin (fig. 1). It is characterised by thick, black mudstone units interbedded with poorly laminated lime mudstones, calcarenitic turbidites and redeposited limestone conglomerates (Hurst \& Surlyk, 1982). In general the formation is very difficult to distinguish from the Wulff Land Formation because of similar lithologies.

In western Nyeboe Land the formation occurs discontinuously between and surrounding the carbonate buildup complex of the Hauge Bjerge Formation (Hurst, 1980) on top of the carbonate platform sequence. In eastern Nyeboe Land, Warming Land, Permin Land and Wulff Land, the formation is more continuous but still has an irregular outcrop pattern. Eastwards along the basin margin, the number of reefs decreases and the Lafayette Bugt Formation forms a more or less coherent unit.

Stratigraphically, the Lafayette Bugt Formation overlies the shelf carbonates and interdigitates with the carbonate buildups of the Hauge Bjerge Formation. In Wulff Land, the base of the formation is exposed at the bottom of the river valley north of Apollo S $\varnothing$ where it concordantly overlies grey platform carbonates of probable Early Silurian age (Hurst \& Peel, 1979). Further northwards, away from the platform margin, the Lafayette Bugt Formation interdigitates with and is overlain by the Wulff Land Formation (fig. 2) (Hurst \& Surlyk, 1982).

The thickness of the Lafayette Bugt Formation is difficult to evaluate because the base is rarely exposed. Thicknesses of the Lafayette Bugt Formation in excess of $150 \mathrm{~m}$ have been measured in Wulff Land, Permin Land and eastern Nyeboe Land. Hurst \& Surlyk (1982) report a thickness of $c .240 \mathrm{~m}$ from Wulff Land, while Dawes \& Peel (1984) noted at least 200 $m$ in central Nyeboe Land (Korsgaard Bjerg).

North of Apollo S $\varnothing$ in Wulff Land, the graptolite Monograptus turriculatus was recovered $10 \mathrm{~cm}$ above the base of the Lafayette Bugt Formation indicating a Late Llandovery $\left(\mathrm{C}_{2-3}\right.$, Fronian) age. The base of the formation is thus slightly older than previously suspected in Wulff Land (Hurst \& Peel, 1979). Approximately $80 \mathrm{~m}$ above the base, the graptolite assemblage Monograptus spiralis, $M$. priodon, Monoclimacis vomerina and Retiolites geinit- 
zianus angustidens indicates a Late Llandovery $\left(\mathrm{C}_{6}\right.$, Telychian) age. The top of the formation has not yet been examined but it probably reaches into the Lower Wenlock riccartonensis Zone (Hurst \& Peel, 1979), a suggestion supported by our finds of the species Monograptus aff. $M$. riccartonensis within the upper part of the formation in western Wulff Land.

In Permin Land, the species Monograptus priodon occurs near the base of the formation ( $180 \mathrm{~m}$ below the top) and indicates a Late Llandovery - Early Wenlock age, while $c .40 \mathrm{~m}$ above the top of the Lafayette Bugt Formation (in the Wulff Land Formation) finds of Monograptus bohemicus may indicate that the formation here is of Late Wenlock or Early Ludlow age.

In Warming Land, the assemblage Retiolites geinitzianus geinitzianus, Monograptus priodon and Monoclimacis vomerina (?)basilica was collected near the base of the formation and indicates a Late Llandovery to Early Wenlock age. This is in agreement with graptolites collected earlier in Warming Land which range from the turriculatus Zone to the sakmaricus-laqueus Zone within the Upper Llandovery (Hurst \& Surlyk, 1982).

In eastern Nyeboe Land, some $150 \mathrm{~m}$ below the top of the formation, a diverse assemblage including Dictyonema sp. aff. D. parallellum, Stomatograptus grandis, Retiolites geinitzianus (?)angustidens, Monograptus spiralis, $M$. priodon, $M$. sp. aff. $M$. tullbergi and Monoclimacis vomerina was collected and indicates the spiralis Zone of the Late Llandovery. Graptolite samples from central Nyeboe Land (Korsgaard Bjerg) described by P. R. Dawes are regarded as being of Ludlow, probably Early Ludlow, age (Berry et al., 1974; Dawes \& Peel, 1984). These graptolite samples may be derived from the upper part of the Lafayette Bugt Formation or from the overlying Wulff Land Formation.

In the type area in Washington Land, the base of the Lafayette Bugt Formation is diachronous between the Middle and early Late Llandovery and extends into the Early Ludlow (Hurst, 1980). In Hall Land, all exposures examined by Hurst \& Surlyk (1982) are Late Llandovery or Early Wenlock, although Dawes \& Peel (1984), on the basis of shelly faunas, report that the formation reaches at least Early Ludlow. It seems likely that the base of the Lafayette Bugt Formation is of Late Llandovery age within the study area and that the formation probably extends into the Late Wenlock or perhaps Early Ludlow.

\section{Wulff Land Formation}

The black mudstone dominated Wulff Land Formation of Hurst \& Surlyk (1982) has its largest outcrop in eastern Wulff Land and to the south in the mapped area; it occurs as a narrow east-west trending belt along the margin of the deep-water basin. The formation underlies the upper mapping unit of the Lauge Koch Land Formation and partly overlies or interdigitates with the Lafayette Bugt Formation (figs 1, 2, 7). Where the Wulff Land and Lafayette Bugt Formations interdigitate they are difficult to distinguish from each other because of very similar lithologies, both being dominated by thick mudstone units (Hurst \& Surlyk, 1982). In the north the Wulff Land Formation interdigitates with the Lauge Koch Land Formation. Here the Repulse Havn and Thors Fjord Members (see below) have been mapped (figs 1, 2,7). The Thors Fjord Member is recognised for the first time in the Wulff Land - Nyeboe land area.

The thickness of the Wulff Land Formation varies between $c .80 \mathrm{~m}$ and $190 \mathrm{~m}$ in sections measured in western Wulff Land, Permin Land, Hendrik $\emptyset$ and eastern Nyeboe Land. An inferred thickness of $500 \mathrm{~m}$ in central Nyeboe Land (Hurst \& Surlyk, 1982, p. 62) probably 
represents the thickness of the Chester Bjerg Formation and not that of the Wulff Land Formation (see below).

In Permin Land, the graptolite Monograptus bohemicus was collected $45 \mathrm{~m}$ above the base of the formation and indicates an Early Ludlow age, while Monograptus (?)chimaera was collected $10 \mathrm{~m}$ below the top of the formation, also indicating a Ludlow age.

In Wulff Land, the base of the Wulff Land Formation is Early Wenlock (Hurst \& Peel, 1979). Some $130 \mathrm{~m}$ from the top of the formation graptolites indicate an Early Ludlow age.

In central Nyeboe Land (Korsgaard Bjerg), graptolites of a Ludlow, probably Early Ludlow, age occur (Berry et al., 1974; Dawes \& Peel, 1984). It is, however, not clear if the strata from which the assemblage was recovered can be referred to the Lafayette Bugt or the Wulff Land Formation.

The available data indicate that the Wulff Land Formation extends from the Early Wenlock into the Early Ludlow, and probably higher.

\section{Thors Fjord Member}

A mudstone unit correlated with the Thors Fjord Member of Hurst \& Surlyk (1982) of the Wulff Land Formation overlies the Merqujôq Formation. It occurs as a narrow strip (because of almost vertical dips) within the Nyeboe Land linear belt from Kap Brevoort in the west to Stephenson $\varnothing$ in the east (fig. 1). The unit was observed in 1966 by P. R. Dawes (Dawes \& Peel, 1984, fig. 3, unit 3B) and mapped from Hendrik $\varnothing$ to Repulse Havn.

The Thors Fjord Member is $94 \mathrm{~m}$ thick at Hand Bugt, Nyeboe Land, and seems to have a fairly constant thickness from Kap Brevoort in the west to Stephenson $\varnothing$ in the east (fig. 1).

Graptolite assemblages collected within the unit at Hand Bugt and on Hendrik $\varnothing$ include Monoclimacis vomerina, Monograptus priodon, M. aff. M. speciosus and Cyrtograptus aff. C. lapworthi, and indicate the Late Llandovery - Early Wenlock transition.

In the northern part of Peary Land the Thors Fjord Member is placed within the Late Llandovery spiralis Zone (Hurst \& Surlyk, 1982). Further south in Peary Land, south of Frederick E. Hyde Fjord, the member extends into the Middle Wenlock. Based on the available graptolite data quoted above, the Thors Fjord Member in the mapped area seems also to extend into the Early Wenlock, which suggests that there is also a westward younging of the top of the member.

\section{Repulse Havn Member}

The Repulse Havn Member of Hurst \& Surlyk (1982) occurs as a narrow strip of almost vertically dipping mudstone dominated sediments within the Nyeboe Land linear belt, and can be traced from Kap Brevoort to Stephenson $\varnothing$ (fig. 1). In western Nyeboe Land, the member overlies the Hand Bugt beds (new informal unit, described below; see also fig. 7), while in north-eastern Nyeboe Land and all the way to Stephenson $\emptyset$, the Repulse Havn Member overlies the chert pebble conglomerates of the Hendrik $\emptyset$ unit A (new informal unit, described below) of the Nordkronen Formation (see below).

The Repulse Havn Member is overlain by the upper mapping unit of the Lauge Koch Land Formation which, at the base east of Hand Bugt, interdigitates with the chert pebble conglomerates of the Hendrik $\emptyset$ unit B (new informal unit, described below).

The stratigraphic thickness of the Repulse Havn Member is more than $50 \mathrm{~m}$ in Hand Bugt 
and is probably of the order of $200 \mathrm{~m}$ in Nyeboe Land (Hurst \& Surlyk, 1982). On Hendrik $\varnothing$, the thickness is approximately $250 \mathrm{~m}$ (Dawes \& Peel, 1984).

Graptolite assemblages collected within the Repulse Havn Member suggest an Early to Middle Ludlow age (Berry et al., 1974; Dawes, 1976; Hurst \& Surlyk, 1982; Dawes \& Peel, 1984).

The Repulse Havn Member can be traced from Nyeboe Land to Stephenson $\emptyset$ (fig. 1), a distance of more than $170 \mathrm{~km}$ along the basin axis (E-W). However, from north to south across the east-west basin axis the post-Silurian regional deformation and folding make it very difficult to trace the Repulse Havn Member southwards. The Repulse Havn Member is time equivalent to the upper part of the mudstone units of the Wulff Land Formation along the southern margin of the turbidite basin (fig. 1). The problem of correlating the lithological units perpendicular to the $\mathrm{E}-\mathrm{W}$ basin axis is discussed in more detail in a later section.

\section{Lauge Koch Land Formation}

The Lauge Koch Land Formation of Hurst \& Surlyk (1982) interdigitates with the Wulff Land Formation. The present mapping has permitted the recognition of a 'lower mapping unit' and an 'upper mapping unit' of the Lauge Koch Land Formation which are informally introduced here. The two units are separated from each other by a distinctive sequence of strata including the Hand Bugt beds, Hendrik $\varnothing$ unit A, Repulse Havn Member and Hendrik $\varnothing$ unit $B$ (figs $1,2,7$ ).

\section{Lower mapping unit (new informal unit)}

The lower mapping unit $(c .850 \mathrm{~m})$ of the Lauge Koch Land Formation overlies the Thors Fjord Member of the Wulff Land Formation and occurs as a distinct linear unit within the Nyeboe Land linear belt from Kap Brevoort in the west to Stephenson $\emptyset$ in the east (fig. 1). The unit is overlain by the Hand Bugt beds.

Lithologically, this lower mapping unit is characterised by buff-yellow to brown weathering medium to thick-bedded fine sandstone turbidites. Thinner-bedded, finer-grained mudstone or siltstone units occur, too, but the sand/mud ratio generally exceeds one.

The lower mapping unit is $852 \mathrm{~m}$ thick at Hand Bugt, and the thickness appears to be fairly constant throughout the more than $170 \mathrm{~km}$ long outcrop along the basin axis (E-W) (fig. 1).

The graptolite Monograptus priodon, collected c. $100 \mathrm{~m}$ above the base of the lower mapping unit at Hand Bugt, places the lowest part of the unit within the Late Llandovery - Early Wenlock (crispus to riccartonensis Zones). The graptolite assemblage Monograptus flemingii and Cyrtograptus cf. C. mancki reported from Repulse Havn in north-western Nyeboe Land (Hurst \& Surlyk, 1982, p. 90) comes from a level some $150 \mathrm{~m}$ below the top of the Lauge Koch Land Formation, from the lower mapping unit, as distinguished here. This graptolite assemblage probably indicates the Late Wenlock lundgreni Zone (Hurst \& Surlyk, 1982).

Taking into account the graptolite assemblages obtained from the underlying Thors Fjord Member, we suggest that deposition of the lower mapping unit in northern Nyeboe Land took place in Wenlock time.

The lower mapping unit only appears within the Nyeboe Land linear belt in the northern part of the mapped area (figs 1,2,7). It is therefore not known if its base and top are di- 
achronous from north to south. Available evidence suggests that the lower mapping unit is not diachronous along the E-W basin axis.

\section{Upper mapping unit (new informal unit)}

The upper mapping unit of the Lauge Koch Land Formation covers about half of the exposed area of the Peary Land Group in the study region (figs $1 \& 2$ ). To the north, in the Nyeboe Land linear belt, the unit overlies the Repulse Havn Member of the Wulff Land Formation and interdigitates with the chert pebble conglomerates of the Hendrik $\emptyset$ units $A$ and $B$ of the Nordkronen Formation (see below). To the south, the unit overlies the Wulff Land Formation and the Lafayette Bugt Formation.

In Nyeboe Land and on Hendrik $\emptyset$, the upper mapping unit interdigitates with the overlying Chester Bjerg Formation forming a transition zone (figs 1, 2, 6).

Like the lower mapping unit of the Lauge Koch Land Formation, the upper mapping unit is characterised by buff-yellow to brown weathering medium to thick-bedded sandy turbidites. Thinner-bedded, finer-grained siltstone and mudstone units occur, too, but the sand/ mud ratio generally exceeds one.

The stratigraphic thickness of the upper mapping unit has not been measured but is estimated at $500-600 \mathrm{~m}$.

No graptolite faunas have been collected from the unit. However, Monograptus (?)chimaera and Monograptus bohemicus have been collected from an interval $40 \mathrm{~m}$ below the base of the unit in Permin Land, indicating that the unit cannot be older than Early Ludlow. Graptolite assemblages collected from just below the base of the unit at the carbonate platform/deep-water basin margin between Nyeboe Land in the west and Wulff Land in the east confirm this age restriction (Hurst \& Surlyk, 1982; Dawes \& Peel, 1984)

To the north the upper mapping unit overlies the Repulse Havn Member which has yielded Early Ludlow graptolite assemblages (Berry et al., 1974; Dawes, 1976; Hurst \& Surlyk, 1982). The upper mapping unit of the Lauge Koch Land Formation seems therefore to be no older than Early Ludlow in the mapped area; available data do not point to any diachronism of the base of the unit.

\section{Hand Bugt beds}

(new informal unit)

The term 'Hand Bugt beds' is introduced here to name a distinctive lithostratigraphic marker horizon. Formal description and definition of the unit is postponed until completion of the mapping in the summer of 1985.

The Hand Bugt beds are characterised by thin-bedded green, silty mudstone turbidites (often bioturbated) interbedded with medium to thick-bedded, calcareous, silty sandstone turbidites. The sandy turbidites have a dark red, rusty weathering colour which is conspicuous throughout the unit. Very often sandstone layers dominated by crinoid and brachiopod debris are associated with the sandy turbidites. Trace fossils are abundant at the soles of the silty, very fine sandstone units.

A detailed sedimentological section through the unit has been measured in Hand Bugt (Larsen \& Escher, unpublished manuscript) and shows a facies association which probably represents a distal outer fan or fan fringe depositional environment. 
The Hand Bugt beds overlie the lower mapping unit of the Lauge Koch Land Formation and occur as a distinct band (due to almost vertical dips) across northern Nyeboe Land, northern Hendrik $\emptyset$ and Castle $\varnothing$. The unit occurs as two distinct layers across northern Wulff Land and southern Stephenson $\varnothing$ (fig. 1), where it interdigitates with the top of the lower mapping unit of the Lauge Koch Land formation. In Nyeboe Land, west of Frankfield Bugt, the Hand Bugt beds are overlain by the Repulse Havn member of the Wulff Land Formation, while to the east in Hendrik $\emptyset$, Castle $\varnothing$, Wulff Land and Stephenson $\varnothing$, the Hand Bugt beds are overlain by the Hendrik $\varnothing$ unit A of the Nordkronen Formation (see below) (fig. 2).

The stratigraphic thickness of the unit is more than $93 \mathrm{~m}$ at Hand Bugt and is of the same order of thickness (more than $80 \mathrm{~m}$ ) on Hendrik $\emptyset$.

Graptolite assemblages collected in the uppermost $50 \mathrm{~m}$ of the unit on Hendrik $\emptyset$ include Pristiograptus dubius aff. (?)ludlowensis. At Repulse Havn the graptolite Bohemograptus bohemicus occurs $10 \mathrm{~m}$ below the top of the unit $(10 \mathrm{~m}$ below the base of the Repulse Havn Member, Hurst \& Surlyk, 1982, p. 70). These graptolites indicate an Early Ludlow age, in agreement with the Early to Middle Ludlow fauna reported from the overlying Repulse Havn Member by Berry et al. (1974), Dawes (1976) and Hurst \& Surlyk (1982), and with the Middle to Late Wenlock fauna from the underlying lower mapping unit of the Lauge Koch Land Formation.

Correlation with the stratigraphy in Peary Land is not possible as the Hand Bugt beds have not been distinguished in that region.

\section{Nordkronen Formation}

Mapping during 1984 demonstrated the presence of two distinct sequences of resedimented chert pebble conglomerates: (1) a lower sequence, here referred to informally as the Hendrik $\varnothing$ unit A which corresponds to the conglomerate zone of Dawes (1966), and (2) an upper sequence referred to here as the Hendrik $\varnothing$ unit B. Both sequences can be traced for considerable distances (figs $1 \& 2$ ).

Outcrop continuity between the two sequences and the Nordkronen Formation in Peary Land (Hurst \& Surlyk, 1982) has not yet been established. However, our field observations indicate (i) that the thickness of the Hendrik $\varnothing$ unit A increases progressively to the east and the unit A probably continues into Nares Land, an area not yet mapped in detail (fig. 1), and (ii) that the conglomerate/sandstone ratio increases progressively to the east, suggesting that the Hendrik $\emptyset$ unit A may gradually be acquiring the lithological characteristics of the Nordkronen Formation as described by Hurst \& Surlyk (1982) from its type area in Peary Land.

\section{Hendrik $\emptyset$ unit A}

(new informal unit)

The lower conglomerate sequence, Hendrik $\varnothing$ unit A, has been mapped as a narrow strip from near Frankfield Bugt in Nyeboe Land, across Hendrik $\varnothing$, Castle $\varnothing$, Wulff Land and Stephenson $\emptyset$, a distance of more than $100 \mathrm{~km}$ (fig. 1). It does not occur west of Frankfield Bugt, but probably continues into Nares Land to the east. The thickness of the sequence increases progressively from west to east: near Frankfield Bugt at least $32 \mathrm{~m}$ is exposed, on 
Fig. 3. Section 16 measured in northern Hendrik $\emptyset$ showing the Hand Bugt beds overlain by the Hendrik $\emptyset$ unit A of the Nordkronen Formation. The type sections of the Hendrik $\emptyset$ Member of Hurst \& Surlyk (1982), sections $13^{1}, 13^{2}$ and 18 , are situated at the top of this section, between $348-363 \mathrm{~m}$.
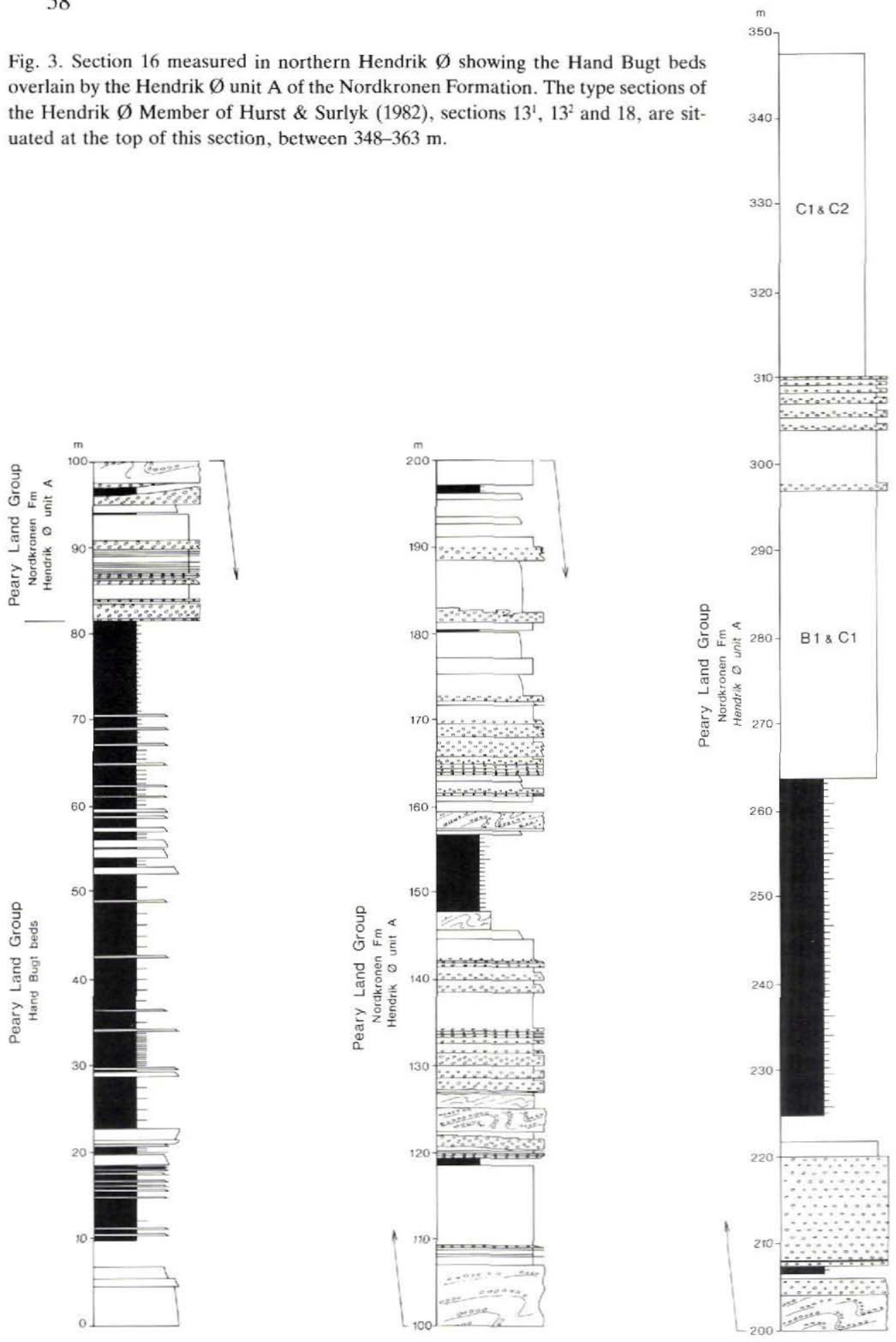


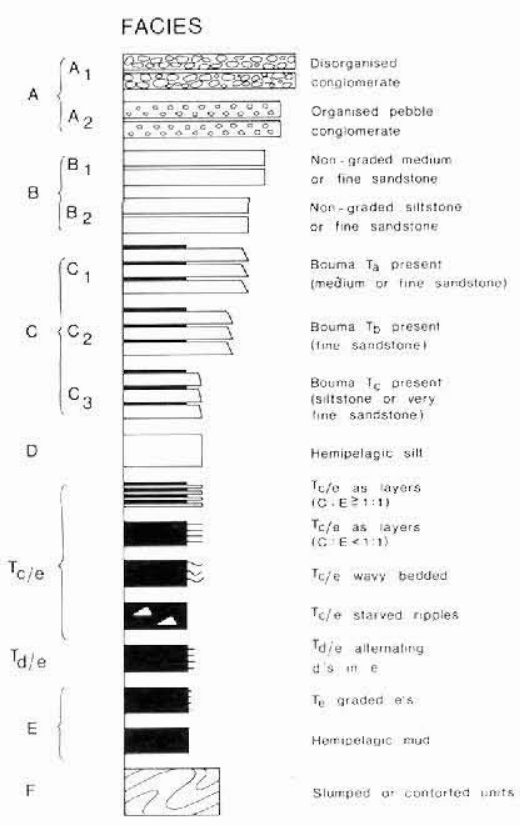

Fig. 4. Facies scheme adopted from Hurst \& Surlyk (1982, fig. 6), slightly modified. The scheme covers all figured sections in the text except fig. 7 .

Fig. 6. Section 13 measured in north-eastern Nyeboe Land showing interfingering sandstone sequences of the Lauge Koch Land Formation (upper mapping unit) and mudstone sequences of the Chester Bjerg Formation.

Fig. 5. Section 15B measured in northern Hendrik $\emptyset$ showing the Hendrik $\varnothing$ unit B of the Nordkronen Formation.

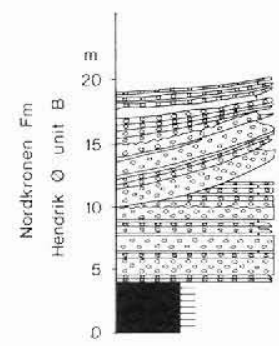

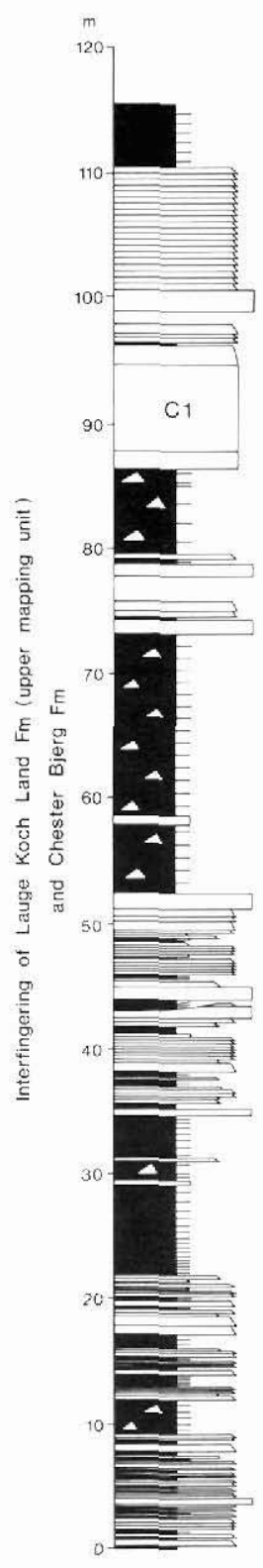


Hendrik $\emptyset 281 \mathrm{~m}$ was measured and on Stephenson $\emptyset$ some $300-400 \mathrm{~m}$ occurs. Unit A overlies the Hand Bugt beds (described above) and is overlain by the Repulse Havn Member of the Wulff Land Formation and the upper mapping unit of the Lauge Koch Land Formation.

Dawes (1966, personal communication) first reported in 1966 the occurrence of a distinct zone of conglomerates within the sandstone turbidites of Hendrik $\varnothing$, Castle $\emptyset$ and Reef $\varnothing$. He introduced the term 'Hendrik Conglomerate' for the conglomerate-rich sequence that was estimated to be up to $250 \mathrm{~m}$ thick (see Dawes \& Peel, 1984, fig. 3, unit 3D). Hurst \& Surlyk (1982) logged in detail only the uppermost beds of the whole sequence of chert pebble conglomerates and defined just these beds as the Hendrik $\emptyset$ Member. In 1984 a section was measured through the sequence from the base of the first chert pebble conglomerate to the top of the last conglomerate - the sequence initially seen by P. R. Dawes. In fig. 3 the entire section is represented with the exception of the uppermost $15 \mathrm{~m}$ (from $348 \mathrm{~m}$ to $363 \mathrm{~m}$ ) which was previously logged by Hurst \& Surlyk (1982, fig. 120). The total thickness of the Hendrik $\emptyset$ unit $A$ is thus $281 \mathrm{~m}$.

Lithologically, the Hendrik $\emptyset$ unit A is characterised by resedimented chert pebble conglomerates interbedded with fine sandstone turbidites and a few mudstone sequences (fig. 3). Stratigraphically upwards, the conglomerate/sandstone ratio decreases and gives way to almost pure fine sandstone and siltstone turbidites at the top. The fine sandstone turbidites are closely associated with the chert pebble conglomerates, and the sequence is interpreted as high-density turbidity current deposits (Hurst \& Surlyk, 1982).

No faunal assemblages have been collected from Hendrik $\emptyset$ unit A, but faunas from underlying and overlying units, noted elsewhere, indicate an Early Ludlow age.

\section{Hendrik $\emptyset$ unit B}

$$
\text { (new informal unit) }
$$

The upper chert pebble conglomerate sequence, here informally designated as the Hendrik $\varnothing$ unit B, was observed by P. R. Dawes in 1966 (personal communication). Hurst \& Surlyk (1982) also recorded the presence of this second conglomerate sequence, but noted that its relationship to their Hendrik $\emptyset$ Member was uncertain. Our mapping shows it to be a discrete upper sequence which outcrops as an irregular narrow strip (due to folding and very steep dips) just south of the Repulse Havn Member. It can be mapped across Castle $\emptyset$, Hendrik $\varnothing$ and into north-eastern Nyeboe Land (fig. 1). Hendrik $\emptyset$ unit B has not been observed east of Castle $\varnothing$. Westwards the sequence occurs in the area just west of Frankfield Bugt, and erratic chert pebble conglomerate blocks at Hand Bugt suggest that it may occur further west. Hurst \& Surlyk (1982), however, do not report chert pebble conglomerates from Repulse Havn. The east-west extension of the unit is therefore limited, and estimated to be of the order of $50 \mathrm{~km}$.

Hendrik $\varnothing$ unit B overlies the Repulse Havn Member and interfingers with the sandy turbidites at the base of the upper mapping unit of the Lauge Koch Land Formation (fig. 2). The thickness of the unit is generally in the order of 15-30 m within the mapping area.

Lithologically, Hendrik $\emptyset$ unit B closely resembles Hendrik $\emptyset$ unit A; resedimented chert pebble conglomerates interbedded with fine sandstone turbidites. The unit is strongly channelled (fig. 5) and stratigraphic sections show great differences even within very short distances. As for Hendrik $\varnothing$ unit A, unit B is interpreted as high-density turbidity current deposits (Hurst \& Surlyk, 1982). 
No faunal assemblages have been recovered from Hendrik $\emptyset$ unit B, but as the member overlies the Repulse Havn Member of the Wulff Land Formation and interfingers with the upper mapping unit of the Lauge Koch Land Formation it cannot be older than Early Ludlow.

\section{Chester Bjerg Formation}

The Chester Bjerg Formation of Hurst \& Surlyk (1982) is the uppermost lithostratigraphic unit of the Peary Land Group. It overlies and interfingers with the upper mapping unit of the Lauge Koch Land Formation in Nyeboe Land and on Hendrik $\emptyset$ (figs 1 \& 2).

The Chester Bjerg Formation is characterised by laminated light green weathering mudstones or siltstones. Its stratigraphic thickness has not been measured, but Dawes (1976) and Hurst \& Surlyk (1982) estimate about 500-800 m.

The interfingering transition zone (figs $1 \& 2$ ) between the Chester Bjerg Formation and the upper mapping unit of the Lauge Koch Land Formation is characterised by packages of fine sandstone turbidites $(10-20 \mathrm{~m})$ alternating with packages of silty mudstones $(5-20 \mathrm{~m})$, often with starved ripples (fig. 6). This facies association reflects a fan fringe depositional environment characteristic of the transition between outer fan and basin plain deposits within the deep-water basin (Hurst \& Surlyk, 1982; Surlyk \& Hurst, 1984).

In the study region, only one graptolite species, Pristiograptus dubius (?)ludlowensis, has been recovered from the Chester Bjerg Formation in north-eastern Nyeboe Land, and indicates an Early Ludlow age. This is the oldest recorded age for the formation which, to the west in Hall Land, reaches the top of the Silurian and possibly extends into the Early Devonian (Bendix-Almgreen \& Peel, 1974; Berry et al., 1974; Bendix-Almgreen, 1976; Lane $e t$ al., 1980; Hurst \& Surlyk, 1982; Dawes \& Peel, 1984). Abundant trace fossils occur in the Chester Bjerg Formation in northern Nyeboe Land.

\section{Distribution and correlation of the lithological units within the deep-water basin}

Apart from the Chester Bjerg Formation and Hendrik $\emptyset$ unit B, all the mapping units of the deep-water basin within the mapped area have a wide distribution along the $\mathrm{E}-\mathrm{W}$ strike of the basin axis (fig. 1). Tracing the lithological units across the basin is, however, more difficult. Only the Chester Bjerg Formation and the upper mapping unit of the Lauge Koch Land Formation can with certainty be traced north-south across the basin (figs 1 \& 2).

At the shelf margin, in the south, an approximately $500 \mathrm{~m}$ thick sequence of Upper Llandovery to Lower Ludlow mudstones and carbonate boulder conglomerates of the Lafayette Bugt Formation and the Wulff Land Formation underlies the upper mapping unit of the Lauge Koch Land Formation (fig. 7A). These clastic sediments overlie the Silurian carbonates which, in central Wulff Land, were referred to Silurian carbonate formations 1-3, with an approximate total thickness of $565 \mathrm{~m}$, by Hurst \& Peel (1979). The latter authors suggested an age range of Early-Late Llandovery for the three carbonate formations and this is largely confirmed by the conodonts (H. A. Armstrong, written communication to GGU). The base of the overlying Lafayette Bugt Formation is of Fronian age (early Late Llandovery - see above). Thus, at this locality, only about $1 \mathrm{~km}$ of Silurian sediments (inclusive of carbonates) of Llandovery to Early Ludlow age underlie the upper mapping unit of the Lauge Koch Land Formation at the platform margin (fig. 7A). The thickness of the carbo- 


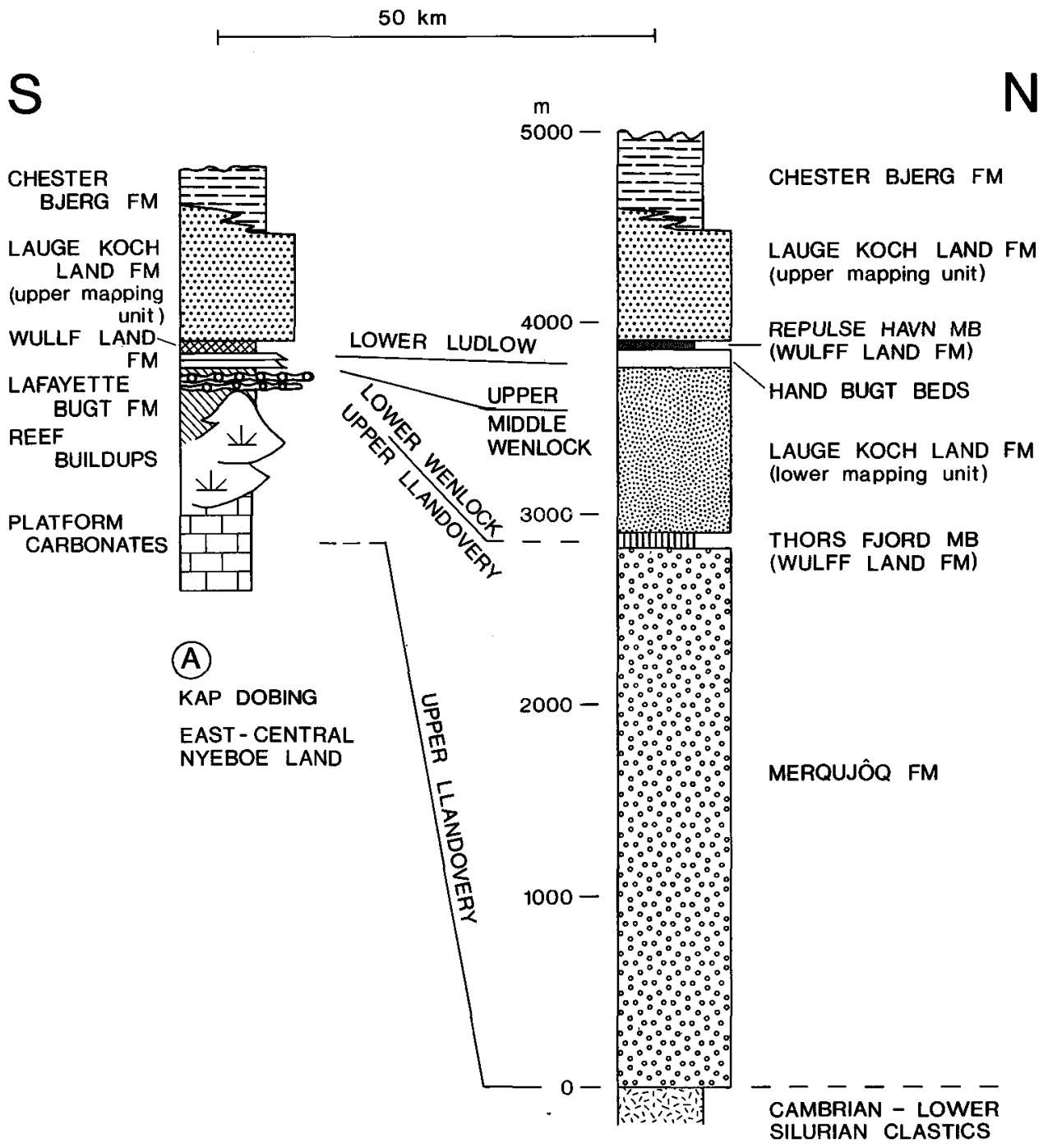

(B)

HAND BUGT
NORTHERN NYEBOE LAND

Fig. 7. Two sections representing the Silurian turbidite sequence: (A) the carbonate shelf/deep-water basin margin at Kap Dobing in eastern Nyeboe Land; (B) the deep-water basin in Hand Bugt, northern Nyeboe Land. 


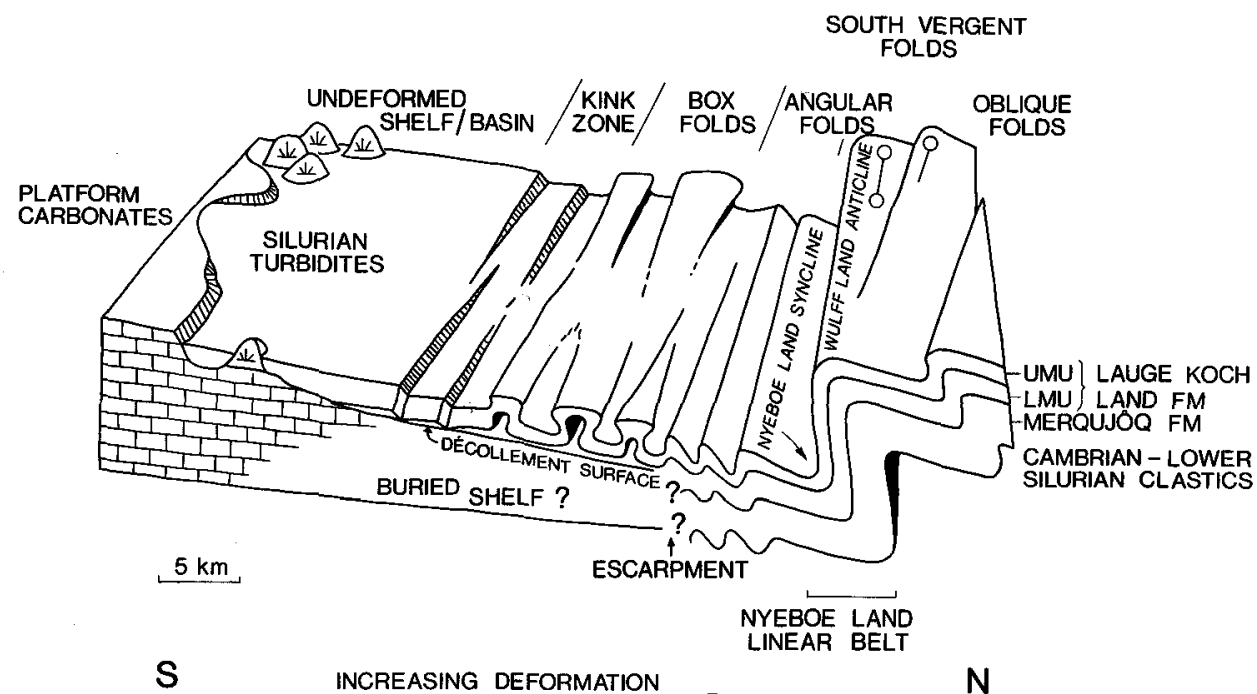

Fig. 8. Tectonogram showing the structural situation in northern Nyeboe Land. UMU and LMU refer to the upper and lower mapping units of the Lauge Koch Land Formation. The tectonic model explains both the sedimentary and the structural observations in northern Nyeboe Land. The model shows surface folds which are the result of presumed buried listric faults and thrusts (not shown in the model). Thin-skinned tectonics also play an important role further to the east in the North Greenland fold belt (Soper \& Higgins, 1985).

nate sequence elsewhere in the mapping area is poorly known and may be somewhat greater than the $565 \mathrm{~m}$ reported by Hurst \& Peel (1979). However, the total thickness at the platform margin is still considerably less than the $4000 \mathrm{~m}$ thick sequence of fine sandstone turbidites of the Merqujôq Formation, the lower mapping unit of the Lauge Koch Land Formation and the Hand Bugt beds, and the mudstones of the Thors Fjord Member and the Repulse Havn Member of the Wulff Land Formation in the deep-water basin to the north (fig. 7B).

The geographical distance between the two sections (fig. 7) is $50 \mathrm{~km}$, but post-Silurian regional deformation and folding (see below) within the northernmost $25 \mathrm{~km}$ of the deep-water basin is responsible for a tectonic shortening of maximum $50 \%$ in that region. The original geographic separation would then have been $c .75 \mathrm{~km}$ which corresponds to an increase in sediment thickness of $3.9 \mathrm{~m}$ per $100 \mathrm{~m}$ progressing northwards into the basin. If $\mathrm{N}-\mathrm{S}$ changes were gradual, this figure would require a primary basin floor slope of at least $2.2^{\circ}$ and would reflect rapid subsidence in the northern and central parts of the basin together with lateral facies changes and wedging out of the formations southwards.

Hurst \& Surlyk (1982, fig. 2) and Surlyk \& Hurst (1984, fig. 29) suggested a continuation of the carbonate shelf to the north beneath the southern part of the deep-water sequence, terminated to the north by an escarpment. This alternative model, here shown in fig. 2 , offers a good explanation of the $\mathrm{N}-\mathrm{S}$ lateral facies and thickness change across the basin and is also supported by the observed structural pattern of post-Silurian deformation and folding within the area. 


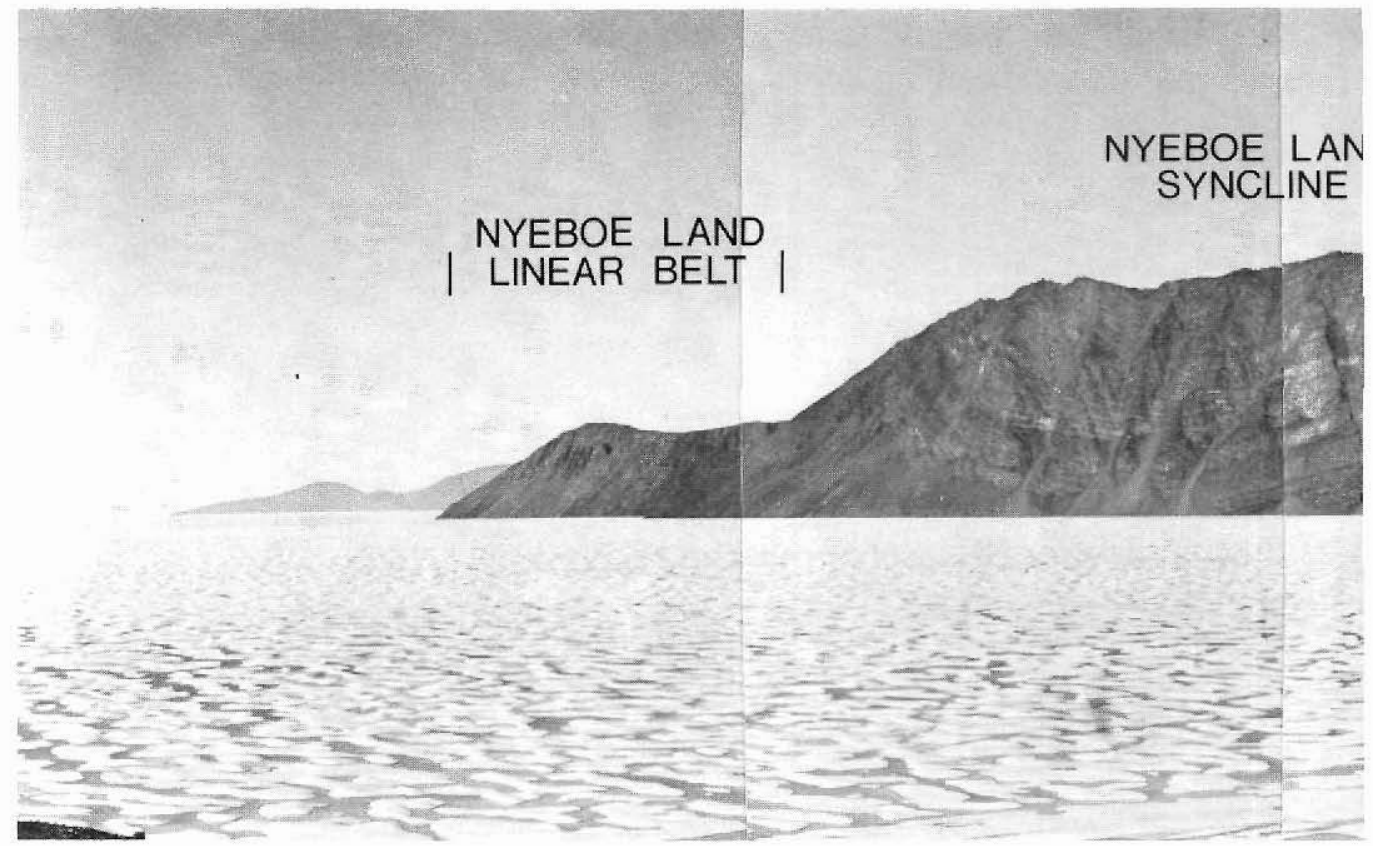

Fig. 9. View towards the east of the west coast of Castle $\emptyset$ showing a section through the Nyeboe Land linear belt, the Nyeboe Land syncline and the angular folds or box folds in an approximately $500 \mathrm{~m}$ high cliff-section.

\section{Structural setting}

The northern part of the deep-water sequence of the Franklinian Basin in North Greenland has been affected by mid-Palaeozoic Ellesmerian regional deformation (Fränkl, 1955; Dawes, 1976, 1982; Dawes \& Soper, 1973, 1979; Higgins et al., 1982).

The local structural situation in central and northern Nyeboe Land is shown in the tectonogram of fig. 8. From south to north the deformation increases progressively: an undeformed zone at the basin margin is succeeded by a zone of monoclines and kinks, and farther north by a zone of box folds. This type of deformation is typical of the classical plis de couverture situation indicating a lack of persistence of folding in depth (Goguel in Carey, 1962). A décollement thrust surface must be implied not far below present-day sea level and is tentatively placed within an incompetent mudstone unit of the Wulff Land Formation overlying the assumed buried carbonate shelf.

Further northwards in Nyeboe Land the zone of box folds gives way to a zone of upright angular folds which, still further to the north, is succeeded by a major south-facing syncline which we have named the Nyeboe Land syncline (figs $8 \& 9$ ). The syncline has an ENEWSW trend with an axial surface dipping some $70^{\circ}$ to the north. Geometrically the structure is remarkably constant and has been traced from Kap Brevoort to Stephenson $\varnothing$, a distance of more than $180 \mathrm{~km}$ (fig. 1).

The northern flank of the Nyeboe Land syncline is composed of an approximately $5 \mathrm{~km}$ 


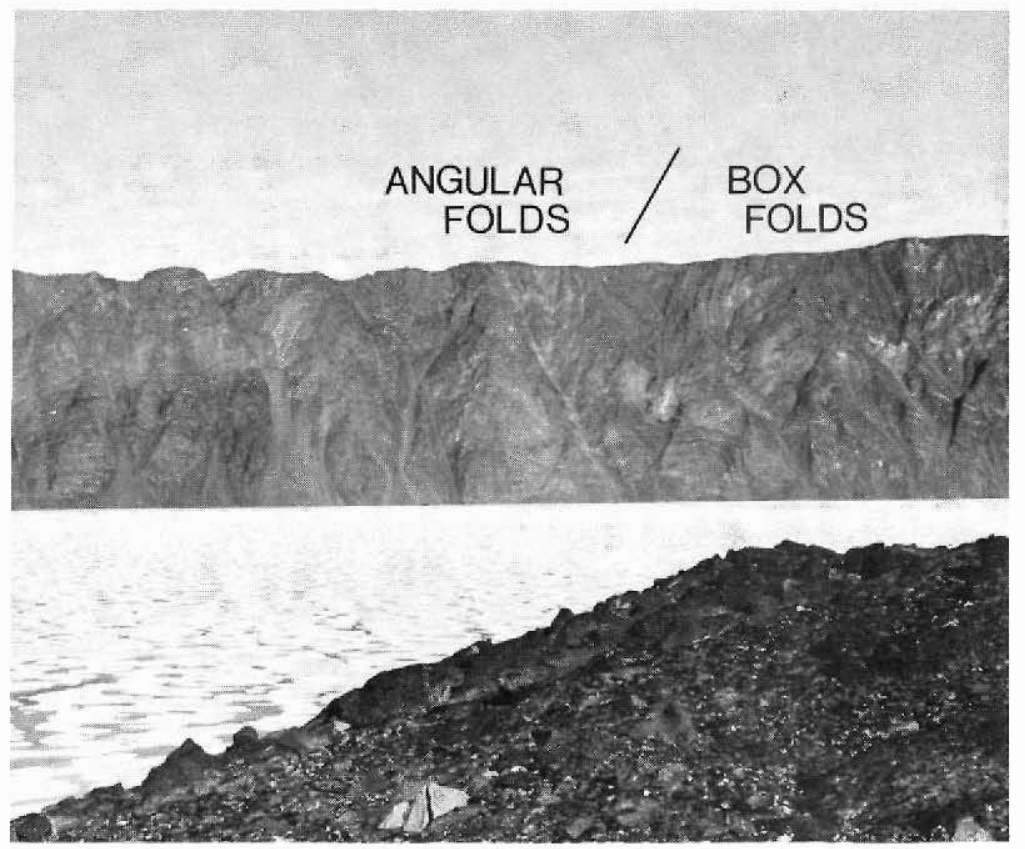

thick sequence of nearly vertical, slightly overturned Silurian turbidites lying within the Nyeboe Land linear belt of Dawes (1982) (fig. 8).

The Nyeboe Land syncline is succeeded to the north by a major south-vergent anticlinal fold, the Wulff Land anticline of Dawes (1982). Cambrian - Lower Silurian siliciclastic deposits are exposed in the core (figs 1 \& 8) (Higgins \& Soper, 1985).

A set of oblique folds are superimposed upon the Nyeboe Land syncline and the Wulff Land anticline (fig. 8); These oblique folds have an E-W orientation which differs slightly from the ENE-WSW trends of the two main structures (fig. 10). In the mudstone units a penetrative axial surface cleavage is associated with the oblique folds. It is not yet clear if the oblique folds and the two major south-vergent folds are the result of only one period of folding or if two separate periods have affected the region.

The tectonogram (fig. 8) thus shows a sharp regional contrast in tectonic style between the central and the northern parts of Nyeboe Land. The central area shows plis de couverture type deformation with small amplitude folds affecting only the uppermost part of the crust, while the northern area shows large amplitude fold deformation implying a deeper tectonic penetration into the crust. The transition between these two regions is remarkably abrupt and can be traced as an almost straight 'tectonic boundary', immediately south of and parallel to the Nyeboe Land syncline from Nyeboe Land over Hendrik $\varnothing$ and Castle $\varnothing$ to Wulff Land. We interpret this tectonic boundary as the reflection of a lithological anisotrophy within the crust represented by a buried carbonate shelf to the south bounded by an escarpment towards a deep siliciclastic basin to the north. The difference in total thickness of the sedimentary sequence south of the Nyeboe Land syncline in the time interval Late Llandovery to Early Ludlow (1065 m, fig. 7A) and within the northern flank of the syncline $(4000 \mathrm{~m}$, 


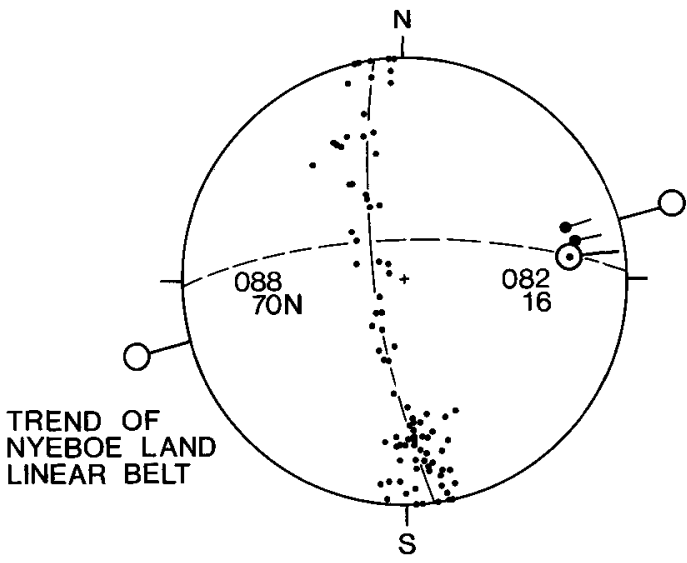

Fig. 10. Stereogram showing structural parameters obtained from the Nyeboe Land linear belt in Hand Bugt, northern Nyeboe Land. Dots: poles to bedding surfaces with the constructed fold axis $082 / 16$ reflecting the orientation of the oblique folds within the linear belt. Broken great circle: axial surface orientation of the oblique folds. The trend of the Nyeboe Land linear belt in northern Nyeboe Land is indicated.

fig. 7B) supports this hypothesis which is an element in the deep-water basin model of Hurst \& Surlyk (1982, fig. 2).

Acknowledgements. We are thankful to P. R. Dawes, A. K. Higgins, J. S. Peel and F. Surlyk for critically reviewing the manuscript and to B. Thomas, E. Glendal and A. Bruun for technical assistance.

\section{References}

Bendix-Almgreen, S. E. 1976: Palaeovertebrate faunas of Greenland. In Escher, A. \& Watt, W. S. (edit.) Geology of Greenland, 534-573. Copenhagen: Geol. Surv. Greenland.

Bendix-Almgreen, S. E. \& Peel, J. S. 1974: Early Devonian vertebrates from Hall Land, North Greenland. Rapp. Grønlands geol. Unders. 65, 13-16.

Berry, W. B. N., Boucot, A. J., Dawes, P. R. \& Peel, J. S. 1974: Late Silurian and early Devonian graptolites from North Greenland. Rapp. Gronlands geol. Unders. 65, 11-13.

Carey, S. W. 1962: Folding. J. Alberta Soc. Petr. Geol. 10, 95-144.

Dawes, P. R. 1966: Lower Palaeozoic geology of the western part of the North Greenland fold belt. Rapp. Grønlands geol. Unders. 11, 11-15.

Dawes, P. R. 1971: The North Greenland fold belt and environs. Bull. geol. Soc. Denmark. 20, 197239.

Dawes, P. R. 1976: Precambrian to Tertiary of northern Greenland. In Escher, A. \& Watt, W. S. (edit.) Geology of Greenland, 248-303. Copenhagen: Geol. Surv. Greenland.

Dawes, P. R. 1982: The Nyeboe Land fault zone: a major dislocation on the Greenland coast along northern Nares Strait. In Dawes, P. R. \& Kerr, J. W. (edit.) Nares Strait and the drift of Greenland: a conflict in plate tectonics. Meddr Grønland, Geosci. 8, 177-192.

Dawes, P. R. \& Peel, J. S. 1984: Biostratigraphic reconnaissance in the Lower Palaeozoic of western North Greenland. Rapp. Grønlands geol. Unders. 121, 19-51.

Dawes, P. R. \& Soper, N. J. 1973: Pre-Quaternary history of North Greenland. In Pitcher, M. G. (edit.) Arctic geology. Mem. Am. Ass. Petrol. Geol. 19, 117-134.

Dawes, P. R. \& Soper, N. J. 1979: Structural and stratigraphic framework of the North Greenland fold belt in Johannes V. Jensen Land, Peary Land. Rapp. Grønlands geol. Unders. 93, 40 pp.

Friderichsen, J. D., Higgins, A. K., Hurst, J. M., Pedersen, S. A. S., Soper, N. J. \& Surlyk, F. 1982: Lithostratigraphic framework of the Upper Proterozoic and Lower Palaeozoic deep water clastic deposits of North Greenland. Rapp. Grønlands geol. Unders. 107, 19 pp. 
Fränkl, E. 1955: Rapport über die Durchquerung von Nord Peary Land (Nordgrönland) im Sommer 1953. Meddr Grønland 103(8), $61 \mathrm{pp}$.

Higgins, A. K. \& Soper, N. J. 1985: Cambro-Ordovician slope and trough stratigraphy between northern Nyeboe Land and western Amundsen Land, North Greenland. Rapp. Grønlands geol. Unders. 126, 79-86.

Higgins, A. K., Mayr, U. \& Soper, N. J. 1982: Fold belts and metamorphic zones of northern Ellesmere Island and North Greenland. In Dawes, P. R. \& Kerr, J. W. (edit.) Nares Strait and the drift of Greenland: a conflict in plate tectonics. Meddr Grønland, Geosci. 8, 159-166.

Hurst, J. M. 1980: Silurian stratigraphy and facies distribution in Washington Land and western Hall Land, North Greenland. Bull. Grønlands geol. Unders. 138, 95 pp.

Hurst, J. M. \& Peel, J. S. 1979: Late Proterozoic(?) to Silurian stratigraphy of southern Wulff Land, North Greenland. Rapp. Grønlands geol. Unders. 91, 37-56.

Hurst, J. M. \& Surlyk, F. 1982: Stratigraphy of the Silurian turbidite sequence of North Greenland. Bull. Gronlands geol. Unders. 145, $121 \mathrm{pp}$.

Hurst, J. M. \& Surlyk, F. 1984: Tectonic control of Silurian carbonate-shelf margin morphology and facies, North Greenland. Bull. Am. Ass. Petrol. Geol. 68, 1-17.

Lane, P. D., Dawes, P. R. \& Peel, J. S. 1980: A new Silurian Hemiarges (Trilobita) from North Greenland and the question of the Polaris Harbour Formation. Rapp. Grønlands geol. Unders. 101, 45-53.

Soper, N. J. \& Higgins, A. K. 1985: Thin-skinned structures at the basin-shelf transition in North Greenland. Rapp. Grønlands geol. Unders. 126, 87-94.

Surlyk, F. 1982: Nares Strait and the down-current termination of the Silurian turbidite basin of North Greenland. In Dawes, P. R. \& Kerr, J. W. (edit.) Nares Strait and the drift of Greenland: a conflict in plate tectonics. Meddr. Grønland, Geosci. 8, 147-150.

Surlyk, F. \& Hurst, J. M. 1983: Evolution of the early Paleozoic deep-water basin of North Greenland Aulacogen or narrow ocean? Geology 11, 77-86.

Surlyk, F. \& Hurst, J. M. 1984: The evolution of the early Paleozoic deep-water basin of North Greenland. Bull. Geol. Soc. Am. 95, 131-154.

Surlyk, F., Hurst, J. M. \& Bjerreskov, M. 1980: First age-diagnostic fossils from the central part of the North Greenland foldbelt. Nature, Lond. 286, 800-803.

Trettin, H. P. \& Balkwill, H. R. 1979: Contributions to the tectonic history of the Innuitian Province, Arctic Canada. Can. J. Earth Sci. 16, 748-769. 